\title{
A TWO YEAR RETROSPECTIVE STUDY OF CONGENITAL INGUINAL HERNIA AT WESTERN REGIONAL HOSPITAL NEPAL
}

\author{
Charles N.R. \\ Mahapatra S.
}

\author{
Christian L.B. $^{2}$ \\ Joshi B.R. ${ }^{5}$
}

Sen T. ${ }^{3}$

\section{ABSTRACT:}

In a retrospective study of 133 cases of inguinal hernia in infants and children upto the age of 14 years, treated surgically at Western Regional Hospital, Pokhara, Nepal between April $1^{\text {st }} 1997$ and March 31 $11^{\text {st }} 1999$, it was found that male patients out number female patients in the ratio of 13.7:1 Right sided hernia was almost twice as common as compared to left. Only $1.5 \%$ of patients (2cases) had bilateral inguinal hernia. 4 patients $(3 \%)$ presented with obstructive features. Routine exploration of contralateral side was not done as most surgeons do not recommend this, as only $20 \%$ develop hernia on the contralateral side. ${ }^{1}$ Only one patient had recurrent hernia.

Key words: Congenital, hernia, inguinal, retrospective, incarceration.

\section{INTRODUCTION:}

An Inguinal hernia is the most common condition requiring operation in the pediatric age group. The incidence of inguinal hernias in children has not been established but is between 10-20:1000 live births. ${ }^{2}$ Hernias can be life threatening or can result in the loss of testis or ovary or a portion of the bowel, if incarceration or strangulation occurs. ${ }^{3}$ Timely diagnosis and operative therapy are thus important if these complications are to be avoided.

The processus vaginalis, which gives rise to usual pediatric indirect inguinal hernia, is present in the de- veloping foetus at 12 weeks of intra uterine life. The processus is a peritoneal diverticulum that extends through the internal inguinal ring and is dragged into the scrotum with the testis. The portion of peritoneum (processus) enveloping the testis becomes the tunica vaginalis. The remainder of the processus within the inguinal canal eventually obliterates, thus eliminating the Fig. 1 the scrotum and the peritoneal cavity. In about $40 \%$, processus vaginalis remains asymptomatically patent throughout life. ${ }^{3}$ The incidence of indirect inguinal hernia in the general population of in-

1. MS General Surgery, Assistant Professor, Manipal College of Medical Sciences, Pokhara, Nepal.

2. MS General Surgery, Assistant Professor, Manipal college of Medical Sciences, Pokhara, Nepal.

3. MS General surgery, Assitant Professor, Manipal College of Medical Sciences, Pokhara, Nepal.

4. MS General Surgery, Lecturer, Manipal College of Medical Sciences, Pokhara, Nepal.

5. $\mathrm{MD}$ (Hons), $\mathrm{PhD}$ (Urology), Head - Department of Surgery, Western Regional Hospital, Pokhara, Nepal.

Address for Correspondence : Dr. Neelam R. Charles, MS General Surgery, Assistant Professor

Manipal College of Medical Sciences, Pokhara, Nepal

Phone No. 00977-61-26630, Fax No. 00977-61-22160, e-mail Address :mcoms@mos.com.np

JNMA, January-March, 2000, 39 
fants and children approximates $1-5 \% .{ }^{4}$ In most series male children with hernias out mumber female children by $8: 1$ to $10: 1$ ratio. ${ }^{1}$ Premature infants have a greatly increased risk for development of inguinal hernias. This high risk of inguinal hernia with risk of incarceration that exceeds $60 \%$ in the $1^{\text {st }} 6$ months of life, ${ }^{5}$ makes surgeons to recommend repair of hernia in infancy.

Additional associated diseases have been found to increase both the incidence of hernia and the risk of recurrence after repair. Patients with cystic fibrosis have upto a $15 \%$ incidence of inguinal hernia. ${ }^{6}$

Direct and femoral hernias in children are extremely rare. The hallmark of an inguinal hernia in a child is a groin bulge extending to the top of the scrotum, which is visible most frequently during periods of increased intra-obdominal pressure eg. crying, laughing, straining. ${ }^{7}$

The treatment of choice for an inguinal hernia is operative repair, an inguinal hernia will not resolve spontaneously. The operation should be carried out electively shortly after diagnosis because of the high risk of later incarceration, especially during first year of life.

\section{MATERIAL AND METHODS:}

The records of all congenital inguinal hernia patients upto the age of 14 years admitted in Western Regional Hospital, Pokhara, from April 1st 1997 to March $31^{\text {st }} 1999$ were examined and data was collected on customized data sheets e.g. age, sex, family history of hernia, presenting symptoms, treatment given, post-operative complications and follow up.

\section{RESULT AND ANALYSIS:}

1.

\begin{tabular}{|l|c|c|}
\hline Sex & Number of patients: & Percentage \\
\hline a. Male & 124 & $93.2 \%$ \\
\hline b. Female & 9 & $6.7 \%$ \\
\hline Total & 133 & $100 \%$ \\
\hline Ratio & $13.7: 1$ & \\
\hline
\end{tabular}

\section{Age : Sex frequency table}

\begin{tabular}{|l|c|r|r|r|r|r|}
\hline $\begin{array}{c}\text { Age } \\
\text { (years) }\end{array}$ & Male & \multicolumn{1}{c|}{$\%$} & Female & $\%$ & Total & $\%$ \\
\hline $0-1$ & 8 & $6 \%$ & 2 & $1.5 \%$ & 10 & $7.5 \%$ \\
\hline $1-2$ & 19 & $14.2 \%$ & 2 & $1.5 \%$ & 21 & $15.7 \%$ \\
\hline $2-3$ & 20 & $15 \%$ & 0 & $0 \%$ & 20 & $15 \%$ \\
\hline $3-4$ & 7 & $5.2 \%$ & 1 & $0.75 \%$ & 8 & $6 \%$ \\
\hline $4-5$ & 18 & $13.5 \%$ & 0 & $0 \%$ & 18 & $13.5 \%$ \\
\hline $5-6$ & 17 & $12.7 \%$ & 1 & $0.75 \%$ & 18 & $13.5 \%$ \\
\hline $6-7$ & 6 & $4.5 \%$ & 1 & $0.75 \%$ & 7 & $5.2 \%$ \\
\hline $7-8$ & 5 & $3.7 \%$ & 0 & $0 \%$ & 5 & $3.7 \%$ \\
\hline $8-9$ & 2 & $1.5 \%$ & 0 & $0 \%$ & 2 & $1.5 \%$ \\
\hline $9-10$ & 8 & $6 \%$ & 0 & $0 \%$ & 8 & $6 \%$ \\
\hline $10-11$ & 2 & $1.5 \%$ & 0 & $0 \%$ & 2 & $1.5 \%$ \\
\hline $11-12$ & 8 & $6 \%$ & 2 & $1.5 \%$ & 10 & $7.5 \%$ \\
\hline $12-13$ & 1 & $0.75 \%$ & 0 & $0 \%$ & 1 & $0.75 \%$ \\
\hline $13-14$ & 3 & $2.2 \%$ & 0 & $0 \%$ & 3 & $2.2 \%$ \\
\hline Total & 124 & $93.2 \%$ & 9 & $6.7 \%$ & 133 & $100 \%$ \\
\hline
\end{tabular}

\section{Side involved}

\begin{tabular}{|c|c|c|c|c|}
\hline \multirow{2}{*}{$\begin{array}{c}\text { No. of } \\
\text { children }\end{array}$} & Right $(\%)$ & left $(\%)$ & Bilateral (\%) & Total (\%) \\
\cline { 2 - 5 } & $82(61.6)$ & $49(36.8)$ & $2(1.5)$ & $133(100)$ \\
\hline
\end{tabular}

\section{Family history of hernia}

\begin{tabular}{|c|c|c|c|c|}
\hline \multirow{2}{*}{$\begin{array}{l}\text { No. of } \\
\text { parents/ } \\
\text { siblings }\end{array}$} & Father $(\%)$ & Mother & Brother $(\%)$ & Sister \\
\hline & $11(8.2)$ & 0 & $2(1.5)$ & 0 \\
\hline
\end{tabular}

\section{Associated anomalies}

$\begin{array}{ll}\text { a. meningocele } & 1(0.7) \\ \text { b. cystic hygroma } & 1(0.7) \\ \text { c. atrial septal defect } & 1(0.7) \\ \text { d. umblical hernia } & 4(3.0) \\ \text { Total } & 7(5.2)\end{array}$

No $(\%)$

$(0.7)$

(3.0)

(5.2) 


\begin{tabular}{ll}
\hline 6. Summary of treatment & \\
a. Operated & $133(100 \%)$ \\
b. Bilateral & $2(1.5 \%)$ \\
c. Unilateral & $131(98.4)$ \\
d. Subsequent contralateral & $2(1.5 \%)$ \\
e. Recurrence & $1(0.7 \%)$
\end{tabular}

\section{Morbidity following herniotomy}

Wound infection 4

Haematoma 1

Recurrent hernia 1

\section{DISCUSSION:}

\section{Age of the patients}

95 out of 133 patients were under the age of 6 years representing $71.4 \%$ in our study. The number of patients less than 1 year of age in our study was only 10 (ie $7.5 \%$ ). This finding is contrary to most studies where $50 \%$ of the patients are less than 1 year of age. ${ }^{2}$ The late presentation may be due to lack of awareness of this surgical problem its and potential complication among the parents.

\section{Side involved}

82 right sided hernia accounted for $61.6 \%$, with a Right : Left ratio of about $2: 1$. This finding corresponds with the observation of congenital inguinal hernias in many series. ${ }^{1,4,7}$

\section{Family history of hernia}

Positive family history was reported in 13 patients (10\%). Louftr et $\mathrm{al}^{8}$ have reported a $11 \%$ positive family history in the series of congenital inguinal hernia treated surgically. In more than $84 \%$ (11/ 13 cases with positive family history), the father had congenital hernia.

\section{Associated anomalies}

Umbilical hernia is commonly associated with inguinal hernia. Increased incidence of hernia among premature babies were reported by Harper et al, ${ }^{9}$ but in ourseries no premature babies presented with inguinal hernia.

\section{Summary of treatment}

All 133 patients had herniotomy. Only 2 patients presented with bilateral hernia for which bilateral herniotomy was done. 4 patients presented with obstructive features, and emergency herniotomy was done and bowel was found to be viable. Only 1 patient had recurrence which was of an indirect inguinal hernia-probably the sac had not been indentified correctly at the initial operation. A high success rate of $>99 \%$ were achieved for our patients who had herniotomy.

\section{COMPLICATIONS:}

Wound infection was the major morbidity as 4 patients $(3 \%)$ had either minor or major wound infections. Only one patient needed secondary suturing. The overall complication rate of elective herniotomy is expected to be $1.7 \% .^{10}$

\section{Follow up}

All patients were followed up for a period of 4-6 months to look for recurrence of hernia or appearance of hernia on the contralateral side, there was 1 recurrence and 2 hernias appeared on the contralateral side.

\section{CONCLUSION:}

1. Herniotomy is a safe and effective operation for hernias in infants and children, with insignificant morbidity/mortality.

2. There is a need for an increase medical awareness among the general population, for early detection and operation.

3. Hernias in infancy and childhood can be easily managed in the department of general surgery in a district referral hospital like Western Regional Hospital, Pokhara.

\section{ACKNOWLEDGEMENT:}

The authors are thankful of Dr Sandhya Charles for her secretarial and technical assistance. Special thanks are due to Dr Digvijay Sharma Timilsina for support and help. 


\section{REFERENCES:}

1. Thomas R Weber, Tom F. Tracy, Jr. Groin hernia and hydroceles Pediatric surgery $2^{\text {nd }}$ edition W B Sanders Company Chapter 46 p562.

2. Stephen $\mathbf{J}$ Shochat. Inguinal hernias. Nelson textbook of pediatric surgery $15^{\text {th }}$ edition W B Sanders company. Chapter 292 p 1116.

3. Morgan EH, Anson BJ. Anotomy of region of inguinal hernia. IV. The internal surface of the parietal layers. Q Bull North - Western Univ Med School 1942; 16:20-28.

4. Cox J A. Inguinal hernia of childhood. Pediatr clin North Am 1985;65:1331-1342.

5. Boocock GR, Todd pj. Inguinal hernias are common in preterm infants. Arch Dis Child 1985;60:669-670.
6. Holsclaw DS, Shwachman H. Increased incidence of inguinal hernia, hydrocele, and undescended testis in males in cystic fibrosis. Pediatrics 1971; 48:442-445.

7. Johnstone JM, Rintoul RF. Operations for hernia. Farquharson's text book of operative surgery. $7^{\text {th }}$ edition. Churchill Livingstone Chapter $24 \mathrm{p} 480$.

8. Louftr AH. Inguinal hernia in infancy and childhood. J Egypt med Assoc 1967, 50:65

9. Harper RG, Garcia A, Sia C. Inguinal herniaA common problem of premature infants weighing 1000 grams or less at birth. Pediatric 1975;56:1.

10. Rowe MI, Marchildon MB. Inguinal hernia and hydrocele in infants and children. Surg clin North Am oct;1981.

\section{ACKNOWLEDGEMENTS}

JNMA editorial board expresses sincere thanks to the following eminent spicialists for peer review of articles for the year 1999.

1. Prof. Kumud Kumar Kafle, MBBS, M.D. Prof. of Pharmacology Institute of Medicine, Kathmandu

2. Prof. P.C. Karmacharya, MBBS, M.D. Department of Ophthalmology Institute of medicine, Kathmandu

3. Dr. Madhav Prasad Khanal, MBBS, DLO E.N.T., Surgeon Bir Hospital, Kathmandu
4. Dr. D.S. Malla, FRCOG Senior Consultant, Co-ordinator, Post Graduate M.D. (obs/ gyn)

Maternity Hospital, Thapathali

5. Dr. D.N. Shah, MBBS, M.D. Associate Professor Department of Ophthalmology Institute of medicine, Kathmandu

6. Dr. Surya Shakya, MBBS, M.D. Assistant Professor Department of Ophthalmology Institute of medicine, Kathmandu 